\title{
Unraveling the connection between GABA and kisspeptin in the control of reproduction
}

\author{
Noelia P Di Giorgio ${ }^{1}$, Marianne Bizzozzero-Hiriart ${ }^{1}$, Carlos Libertun ${ }^{1,2}$ and Victoria Lux-Lantos ${ }^{1}$ \\ ${ }^{1}$ Instituto de Biología y Medicina Experimental (IBYME-CONICET), Buenos Aires, Argentina and ${ }^{2}$ Departamento de \\ Fisiología, Facultad de Medicina, Universidad de Buenos Aires, Buenos Aires, Argentina
}

Correspondence should be addressed to V Lux-Lantos; Email: vlux@lantos.com.ar

\begin{abstract}
Neuroendocrine control of reproduction involves the interplay of various factors that become active at some point along development. GnRH is the main neurohormone controlling reproduction and among the most important inputs modulating GnRH synthesis/secretion are GABA and kisspeptins. These interactions of GABA and kisspeptin in the control of GnRH secretion can take place by the presence of the receptors of both factors on the GnRH neuron or alternatively by the actions of GABA on kisspeptin neurons and/or the actions of kisspeptin on GABA neurons. Kisspeptin acts on the Kiss1R, a seven transmembrane domain, $\mathrm{G}_{\alpha q / 11^{-}}$ coupled receptor that activates phospholipase $C$, although some $G_{\alpha q / 11}$-independent pathways in mediating part of the effects of Kiss1 R activation have also been proposed. GABA acts through two kinds of receptors, ionotropic GABAA/C receptors involving a chloride channel and associated with fast inhibitory/stimulatory conductance and metabotropic GABAB receptors (GABABR) that are $\mathrm{G}_{\mathrm{i} / \mathrm{0}}$ protein linked inducing late slow hyperpolarization. In this review, we aim to summarize the different ways in which these two actors, kisspeptin and GABA, interact to modulate $\mathrm{GnRH}$ secretion across the reproductive lifespan.

Reproduction (2019) 157 R225-R233
\end{abstract}

\section{Introduction}

Reproduction is a fundamental feature of all known life and is essential for the perpetuation of the species. In mammals reproduction is under tight neuroendocrine control, and it involves the interplay of endocrine factors, neurons and various neurotransmitters and neuropeptides that become active at some time along development. The interaction of all these factors translates the information of environmental and internal cues into a specific timing and pattern of hormone secretion that will enable reproduction when it has the highest chances of being successful. The gonadotropinreleasing hormone $(\mathrm{GnRH})$ neurons represent the final output pathway of the neuronal network controlling reproduction in all mammalian species. The regulation of $\mathrm{GnRH}$ secretion depends on numerous inputs into $\mathrm{GnRH}$ neurons, which have been the aim of intense investigations for many years. Among these many inputs, the salient ones include kisspeptin (de Roux et al. 2003, Seminara et al. 2003), GABA (Donoso \& Banzan 1986, Akema \& Kimura 1991, Robinson et al. 1991, Keen et al. 1999) and glutamate (Gay \& Plant 1987, Urbanski \& Ojeda 1987, Suzuki et al. 1995, Gore et al. 1996).

GABA is the main inhibitory neurotransmitter in the mammalian central nervous system. It acts through two kinds of receptors, ionotropic GABAA/C receptors involving a chloride channel and associated with fast inhibitory/stimulatory conductance events, and metabotropic GABAB receptors (GABABR) that are $\mathrm{G}_{\mathrm{i} / 0}$ linked inducing late, slow hyperpolarization, diminution in membrane $\mathrm{Ca} 2+$ conductance by voltage-sensitive calcium channels (VSCC), increase in membrane $\mathrm{K}+$ conductance (Kir-3) and inhibition of adenylyl cyclase. Pharmacologically, these receptors differ in their response to agonists and antagonists.

GABAARs are agonized by muscimol and antagonized by bicuculline, gabazine, picrotoxin, PHP 501 trifluoroacetate, SR95531, among others.

$\mathrm{GABAB}$ receptors are typically agonized by baclofen and antagonized by phaclofen, 20-hydrxysaclofen, CGP55845, CGP52432, SCH50911, among others.

It is now well established that GABA plays more than an inhibitory role and can function as an important stimulatory developmental signal early in life (Lauder et al. 1998, Ziskind-Conhaim 1998, Fiszman \& Schousboe 2004, Galanopoulou 2008, Tobet et al. 2009, Kilb et al. 2013). In the study of GABA as a neurotransmitter, neurohormone or neurotrophic signal, its actions through the GABAAR have gained maximal attention, while its actions through the GABABR have been less well studied. Nevertheless, GABA acting on GABABRs has many important effects that are slowly coming to light. For example, it has been recently demonstrated that activation of metabotropic GABABRs in cortical layer 1 can powerfully inhibit principal 
cell activity and that their activation can rapidly halt ongoing network activity (Craig \& McBain 2014). In addition, GABABRs promote radial migration into the upper cortical plate and tangential migration of interneurons (Luhmann et al. 2015). GABABRs also regulate crucial steps of neuronal network formation, including migration, neurite growth, synapse formation and plasticity (Gaiarsa \& Porcher 2013).

GABA contributes to the neural circuits that control reproduction during the whole life span. GABAergic afferents are known to be among the major synaptic inputs to GnRH neurons (Leranth et al. 1985). There are conflicting reports on whether GABA is stimulatory or inhibitory on $\mathrm{GnRH}$ release. While the net effect of increased GABA within the POA seems to inhibit $\mathrm{GnRH}$ secretion (Han et al. 2004), direct action of GABA on GnRH neurons induced GABAAR-mediated excitation (DeFazio et al. 2002). Currently, there is growing consensus that GABA can act through the GABAARs to exert both depolarizing and hyperpolarizing effects on $\mathrm{GnRH}$ neurons, but the predominant action seems to be that of excitation, while the effect of GABAB receptor stimulation is always inhibitory (Herbison \& Moenter 2011).

GABA participates in the migration of $\mathrm{GnRH}$ neurons from the olfactory placode into the hypothalamus during embryonic development (Fueshko et al. 1998, Tobet et al. 2001, Wierman et al. 2011, Gaiarsa \& Porcher 2013). Moreover, it contributes to puberty onset and the regulation of the preovulatory LH surge in adult females (Jarry et al. 1995, Terasawa \& Fernandez 2001, Clarkson \& Herbison 2006, Maffucci \& Gore 2009, Moenter et al. 2009). Some of these effects are exerted directly on $\mathrm{GnRH}$ neurons, while others are exerted by interneurons as, for example, kisspeptin neurons.

Kisspeptin, encoded by the Kiss 1 gene, plays an essential role in the control of reproduction as has been shown by the groundbreaking works of de Roux et al. and Seminara et al. who demonstrated in 2003 that inactivating mutations of the GPR54 (Kiss1r) gene were associated with hypogonadotropic hypogonadism in humans and mice (de Roux et al. 2003, Seminara et al. 2003). Since then, kisspeptin signaling has been identified as one of the critical regulators for both puberty onset and maintenance of normal reproduction in mammals, as well as also participating in metabolic control and behavior, among other functions (Kaiser \& Kuohung 2005, Dungan et al. 2006, Seminara 2006, Roa et al. 2008, Kauffman \& Smith 2013, Beltramo et al. 2014, Millar \& Babwah 2015, Ronnekleiv et al. 2015, Liu \& Herbison 2016, Lehman et al. 2018).

In adult rodents kisspeptin is mainly expressed in two hypothalamic regions, the anteroventral periventricular nucleus and neighboring periventricular nucleus (AVPV/ PeN) and the arcuate nucleus (ARC). Kiss 1 expression in the AVPV/PeN is sexually dimorphic, being more abundant in adult females than in males, while Kiss 1 expression in the adult ARC does not show evident sex differences (Semaan et al. 2013). Additional extrahypothalamic regions of Kiss 1 expression have been identified such as the lateral septum (LS), bed nucleus of the stria terminalis (BNST) and the medial amygdala (MeA) (Clarkson et al. 2009, Cravo et al. 2011, Kim et al. 2011, Di Giorgio et al. 2014, Pineda et al. 2017), areas with an important role in the modulation of various social and sexual behaviors.

As we mentioned earlier, both kisspeptin and GABA are important modulators of the hypothalamichypophyseal-gonadal axis. Here, we aim to unravel the interplay between GABA and kisspeptin in the control of reproduction by addressing the effects of GABA on both GABAA and GABAB receptors, mainly from evidence in rodents. These interactions in hypothalamic nuclei will be examined in three developmental phases: perinatal, peripubertal and adult. Kisspeptin and GABA interactions will also be analyzed in extra-hypothalamic sites that modulate reproduction in several ways such as sexual behavior.

\section{Interactions of kisspeptin and GABA in the hypothalamus}

\section{Perinatal period}

It has been postulated that perinatally Kiss 1 expression is detected in the ARC but not so readily in the AVPV/PeN, where it only appears at approximately postnatal day 10 (PND10) and starts to show the sexually dimorphic expression (females $>$ males) on PND12 (Semaan et al. 2013). Nevertheless, more recent work demonstrated the presence of a male-specific population of pre-optic area kisspeptin neurons that appear transiently in the perinatal period: neurons positive for kisspeptin protein were first detected on E17, increasing in number over E19 to reach a peak on the day of birth before declining to zero on PND5. These kisspeptin neurons provide one possible source of kisspeptin drive to neonatal $\mathrm{GnRH}$ neurons and consequent neonatal testosterone production in the mouse that is fundamental for the sexual differentiation of the brain after aromatization to estradiol (Clarkson \& Herbison 2016). The fast decline in these neurons is probably a consequence of the perinatal testosterone surge they elicit.

Regarding the ARC, expression of Kiss 1 mRNA in embryonic rodents was determined in both sexes around E11.5 in rats and E13 in mice and increased by E18.5, with a sharp drop in levels just prior to birth (Semaan et al. 2013). Although there are no consistent sex differences in ARC Kiss 1 expression in adulthood, early postnatally ARC Kiss 1 mRNA expression is higher in females than in males and this lasts from birth until the juvenile period begins (PND11). Whether these early sex differences are also observed during embryological life remains controversial. Perinatal male testosterone 
secretion also induces the early loss of ARC Kiss 1 expression in males (Semaan et al. 2013), allowing for the sex differences observed early postnatally.

Interestingly, one of the mediators of the sexdifferentiating actions of testosterone/estradiol is GABA (McCarthy et al. 2002), particularly in the ARC (McCarthy et al. 2008).

In addition to its sex-differentiating effects, and as we mentioned earlier, GABA modulates GnRH neurons early during embryogenesis by modulating their migration from the olfactory placode into the hypothalamus (Fueshko et al. 1998, Tobet et al. 2001, Wierman et al. 2011, Gaiarsa \& Porcher 2013). These GnRH neurons express both GABAA and GABAB receptors (Tobet et al. 2001). Whether a similar interaction between GABAergic and Kiss 1 neurons exists at this early stage of development remains unknown. Adult Kiss 1 neurons express GABAA (Ducret et al. 2010, Gottsch et al. 2011, Alreja 2013) and GABAB receptors (Di Giorgio et al. 2014). However, it is not known when Kiss 1 neurons commence to express these receptors and to be modulated by GABA.

A recent study evaluated the effect of GABAAR activation on Kiss 1 gene expression in a rat hypothalamic kisspeptin-producing cell line derived from immortalized E18 hypothalamic primary cultures, the rHypoE8 cells and in primary cultures of the neuronal cells of fetal rat brains. They found that muscimol could actually stimulate Kiss 1 gene expression in both models (Kanasaki et al. 2017). Interestingly, when rHypoE8 cells were stimulated with GABA instead of muscimol, this stimulatory effect was not observed, suggesting that GABABRs also activated by GABA may have a contrary effect on Kiss 1 expression. These results hint to active GABA receptors at this developmental age; nevertheless, in these models, a direct action of GABA on kisspeptin neurons cannot be asserted, as in both cases, the cell populations did not consist exclusively of kisspeptin neurons.

We have observed that at PND4 the well-described sex difference in ARC Kiss 1 expression (females > males) was abolished in mice lacking functional $G A B A B$ receptors (GABAB1KO). Kiss1 mRNA expression was downregulated in females attaining male levels ( $\mathrm{Di}$ Giorgio et al. 2013). Interestingly, at this postnatal age, we found increased AVPV/PeN Kiss 1 mRNA expression in males with regard to females, in agreement with Clarkson and Herbison (Clarkson \& Herbison 2016), without any genotype difference. These results suggest a possible participation of GABABRs in establishing nucleus-specific sex difference in Kiss 1 expression, with effects in the ARC but not in the AVPV/PeN. In order to evaluate GABAB receptor effects in ARC kisspeptin expression by a pharmacological approach, $\mathrm{BALB} / \mathrm{c}$ pups were injected from PND2 to PND6 with the GABAB antagonist CGP55845 or with saline and were killed on PND6. Kiss 1 mRNA expression in ARC punches showed the expected sex difference in saline- treated mice (females $>$ males). CGP55845 induced significant downregulation of Kiss 1 expression in both males and females (Bizzozzero et al. 2017). However, in CGP55845-injected mice, the sex difference was maintained, showing somewhat different effects from those observed in GABAB1KO mice, in which GABABRs are missing from conception onward. No effect on AVPVPeN Kiss 1 expression was observed by treatment with the GABAB antagonist, reinforcing that the modulation by GABABRs is nucleus specific. Again, in both these genetic and pharmacological approaches, direct actions of GABA on kisspeptin neurons cannot be verified.

Interestingly, Kiss 1 expression in the APVP/PeN and ARC of adult GABAB1 KO mice is similar to WTs (Di Giorgio et al. 2014). Moreover, CGP55845 injection to adult mice did not modify Kiss 1 expression in either nucleus (Bizzozzero et al. 2017), demonstration that the effect of GABAB receptor modulation on ARC Kiss 1 expression depends on the stage of development. As adult GABAB1KO mice have compromised reproduction (Catalano et al. 2005), we postulate that the distortion in neonatal ARC Kiss 1 expression may influence the programming of the reproductive network. This hypothesis is currently under investigation.

To our knowledge, there is no description of direct GABA actions on kisspeptin neurons modifying kisspeptin expression, synthesis, secretion or function at this early developmental phase.

\section{Peripubertal period}

In rodents, AVPV/PeN Kiss 1 expression shows a steady and continuous increase in cell number from PND15 through PND28, at which point it attains adult levels; the sex difference (females $>$ males) was first detected at PND12 and robustly observed as from PND16 (Semaan et al. 2013).

In the ARC, the number of Kiss 1 neurons rise moderately over the pubertal transition reaching adult levels around the time of vaginal opening in females, with older pubertal ages (PND28-30) being significantly higher than earlier pubertal ages (PND20-22) (Semaan \& Kauffman 2015). As mentioned earlier, in the adult ARC, Kiss 1 mRNA expression is not majorly different between males and females, especially when circulating sex steroid levels are equalized between the sexes (Semaan et al. 2013). Nevertheless, some studies show increased ARC kisspeptin immunoreactivity in adult gonadally intact and gonadectomized female mice with regard to males (Budefeld et al. 2016).

Regarding the interaction of GABA and kisspeptin during this stage of development, in monkeys, it has been proposed that there is a central restrain of $\mathrm{GnRH}$ release prior to puberty and that GABA, acting on GABAAR, is a crucial component of this inhibition. Blocking GABAAR in prepubertal monkeys stimulated kisspeptin release in the medial basal hypothalamus that in turn 
stimulated GnRH secretion, but this was not observed after puberty onset, suggesting that there is a decline in GABA inhibition at this time point. These results suggest that kisspeptin neurons may relay inhibitory GABA signals to GnRH neuron before puberty (Terasawa et al. 2010, Kurian et al. 2012). A similar mechanism is also proposed to be active in humans (Check 2013). Whether a similar mechanism is also present in rodents is still under investigation.

Regarding GABAB receptors, female GABAB1KO mice showed normal puberty onset (Catalano et al. 2005), suggesting that GABAB receptors do not participate in this process.

\section{Adulthood}

Most of the work on the interaction of GABA and kisspeptin in the control of reproduction has been performed in adult mice, especially in females. An early electrophysiological work indicated that kisspeptin activated $\mathrm{GnRH}$ neurons via both direct and transsynaptic mechanisms (Pielecka-Fortuna et al. 2008). Transsynaptic mechanisms were either enabled and/or potentiated by estradiol. The AVPV/PeN expresses Kiss $1 r$, and this region is rich in GABAergic, glutamatergic and dual GABA/glutamatergic neurons that project to $\mathrm{GnRH}$ neurons. Pielecka-Fortuna et al. demonstrated that kisspeptin increased GABAergic and glutamatergic transmission directly to GnRH neurons in an estradioldependent manner and that kisspeptin increased $\mathrm{GnRH}$ neuron response to activation of GABAA receptors (Pielecka-Fortuna \& Moenter 2010), demonstrating that kisspeptin modifies GABAergic transmission to $\mathrm{GnRH}$ neurons at the time of the preovulatory surge.

Interaction of kisspeptin with GABA was further proposed by Neal-Perry et al. who showed that specifically, age-related changes in LH surge amplitude may be causally linked to reduced Kiss 1 mRNA expression in the AVPV, reduced mPOA glutamate and increased mPOA GABA release (Neal-Perry et al. 2009). Interestingly, kisspeptin infusion into the mPOA of estradiol-primed rats rescued $\mathrm{GnRH} / \mathrm{LH}$ release and elevated local glutamate and decreased local GABA release, thereby restoring the balance of local excitatory and inhibitory amino acid release in the mPOA of middle-aged rats to levels typical of young females. Thus, an inhibitory effect of kisspeptin on GABA neurons is suggested here, at least in this particular animal model of middle-aged rats. Together, these results suggest that the effect of kisspeptin on GABA release may depend on the endocrine milieu.

It has been suggested that Kiss 1 neurons may also coexpress additional neurotransmitters. Using transgenic mice Cravo et al. (2011) described that in AVPV/PeN approximately $20 \%$ of Kiss 1 neurons coexpressed vGluT2 mRNA, a marker for glutamatergic neurons, and 75\% coexpressed Gad1 mRNA, a marker for GABAergic neurons. In the AVPV/PeN neurons expressing the three genes, Kiss1, Gad1 and vGlutT2 mRNAs, were also observed. Therefore, neurons containing GABA and kisspeptin may simultaneously or sequentially secrete these neurotransmitters to modulate $\mathrm{GnRH}$ neurons. In the ARC, $90 \%$ of Kiss 1 neurons coexpressed vGluT2 mRNA and $50 \%$ of these also coexpressed Gad $1 \mathrm{mRNA}$. However, another more recent study, described very limited coexpression of kisspeptin and GABA in ARC neurons in both males and females (Marshall et al. 2017).

Further electrophysiological studies on the impact of AVPV/PeN stimulation on GnRH neuron excitability (Liu et al. 2011) demonstrated that a high percentage of $\mathrm{GnRH}$ neurons located in the rostral POA received monosynaptic inputs from this area. AVPV/PeN stimulation at low frequencies $(1 \mathrm{~Hz})$ generated shortlatency action potentials in GnRH neurons with GABA and glutamate mediating $90 \%$ of the evoked fast synaptic currents. They found that the AVPV/PeN GABA input through GABAARs was dominant and excited or inhibited $\mathrm{GnRH}$ neurons in a cell-dependent manner. Increasing the AVPV/PeN stimulation frequency to $5-10 \mathrm{~Hz}$ resulted in the appearance of additional post stimulus inhibitory response, attributed to GABABRs, as well as a delayed excitatory response that was mediated by kisspeptin. In this study, it could not be established whether GABA, glutamate and kisspeptin release originated from the same neuron or from independent sets of neurons. In a very recent follow-up on these studies, Piet et al. demonstrated with a state-of-the-art optogenetic approach that there is effectively an AVPV/ $\mathrm{PeN}$ neuron population that coexpresses kisspeptin and GABA and that this population provides an important double excitatory input to $\mathrm{GnRH}$ neurons with kisspeptin being the dominant stimulus in activating $\mathrm{GnRH}$ neurons at the time of ovulation (Piet et al. 2018).

In addition to kisspeptin modulating GABA neurons and the existence of neurons expressing both kisspeptin and GABA, there exists also evidence that GABA can modulate kisspeptin neurons.

When analyzing the actions of GABA on AVPV/PeN and ARC Kiss 1 neurons, an inhibition of Kiss 1 neuron firing was observed when GABAARs were activated (Ducret et al. 2010, Gottsch et al. 2011, Alreja 2013); this could be relevant to various reproductive states including the estrous cycle. In hypothalamic slices from animals with GFP-marked kisspeptin neurons, DeFazio et al. (2014) demonstrated that both estradiol and time of day influenced GABAergic transmission to hypothalamic kisspeptin neurons as well as their response to GABA through GABAARs. While GABA generally hyperpolarized AVPV/PeN kisspeptin neurons, there was an estradiol-induced decrease in GABAergic input to these neurons in the afternoon of ovariectomized estradiol-treated (OVX-E) mice, allowing for the increase in kisspeptin output. Conversely, GABAAR stimulation induced 
depolarization of ARC kisspeptin neurons although not likely to induce excitation. In the presence of estradiol this depolarization could be sufficient to inactivate voltage-gated sodium channels and result in an increased threshold for action potential firing ('depolarizing inhibition'), consistent with the current view that steroid negative feedback is conveyed to $\mathrm{GnRH}$ neurons at least in part by inhibition of ARC kisspeptin neurons. These estradiol-modulated effects of GABA on both kisspeptin neuron populations may be critical for eliciting the preovulatory LH surge.

Additional work suggested a critical role for GABA in the elicitation of the preovulatory kisspeptin/GnRH/LH surges. Leon et al. working with global Grp54 KO mice and with GnRH Gpr54-/-Tg-rescued mice, in which the Gpr54 gene was selectively reintroduced into GnRH neurons, provided conclusive evidence that the GABAA receptor blockade-induced increase in $\mathrm{LH}$ secretion is completely dependent on kisspeptin signaling to $\mathrm{GnRH}$ neurons, as LH secretion was abolished in global Grp54 $\mathrm{KO}$ and recovered in GnRH Gpr54-/-Tg rescued mice (Leon et al. 2016).

A very interesting work evaluated the effect of GABA, acting on GABABRs, on kisspeptidergic neurons. It has been shown that burst firing facilitates neuropeptide release from neurons. In order to attain a 'preovulatory' release of kisspeptin these neurons probably depend on burst firing. While studying the biophysical properties of Kiss 1 neurons in the AVPV-PeN, Zhang et al. (2013) observed that the crucial T-type calcium current necessary for rebound burst firing was present in these Kiss 1 neurons and that this phenomenon was estrogen dependent. The presence of a robust T-current is essential for the high-frequency rebound bursting that is manifested following a hyperpolarizing stimulus, and they demonstrated that this hyperpolarizing stimulus was delivered to Kiss 1 neurons by GABABR agonists, such as baclofen, and also by $\mu$ - and $\kappa$-opioid agonists, suggesting that these pathways contribute to the preovulatory release of kisspeptin (Zhang et al. 2013). They confirmed the presence of $\mu$ and $\kappa$ opioid receptor mRNA in these Kiss 1 cells. Consistent with the effect they described with a GABAB agonist, 98\% of AVPV-PeN Kiss 1 neurons express the Gabab1 subunit mRNA of the GABAB receptor (Di Giorgio et al. 2014). Adult GABAB1KO females showed normal Kiss 1 expression in the AVPV-PeN and ARC; however, they have compromised reproduction (Catalano et al. 2005). Although Kiss 1 expression was not altered in the AVPV$\mathrm{PeN}$, taking into consideration the results observed by Zhang et al. (2013) described earlier, the absence of GABAB signaling to Kiss 1 neurons may jeopardize the hyperpolarizing input to kisspeptidergic neurons necessary for the high-frequency rebound bursting activity contributing to the preovulatory kisspeptin surge. This hypothesis is currently under investigation in our laboratory.
An alternative way in which GABABRs and kisspeptin interact in the control of reproduction is directly at the GnRH neuron that expresses both GABABRs and KISS1R. On the one hand, the GABABR agonist baclofen hyperpolarized $\mathrm{GnRH}$ neurons through activation of an inwardly rectifying $\mathrm{K}+$ current (Kir) in a concentrationdependent manner, providing an inhibitory tone. On the other hand, kisspeptin depolarizes $\mathrm{GnRH}$ neurons through $\mathrm{G}_{\alpha \mathrm{\alpha} / 11}$-phospholipase $\mathrm{C}$ signaling-mediated inhibition of these same Kir channels as well as through activation of a canonical transient receptor potential (TRPC)-like cationic channel (Zhang et al. 2008). Therefore, in the presence of estradiol, such as in proestrus, strong kisspeptin stimulation will attenuate the $G A B A B$ inhibitory input, as they use the same mechanism in opposite directions to exert their effects (Zhang et al. 2009).

Reproduction and metabolism are closely related, and it has been demonstrated that leptin is a major participant in this coordination (Barash et al. 1996, Chehab et al. 1996, de Luca et al. 2005). When trying to identify the nature of leptin-responsive neurons mediating these effects in female mice, Martin et al. (2014) demonstrated that leptin-responsive GABAergic neurons, but not glutamatergic neurons, act as metabolic sensors to regulate fertility. Lack of leptin receptors on GABAergic neurons impaired reproduction and normal kisspeptin response to OVX in the ARC and to OVX-E in the AVPV/ $\mathrm{PeN}$. These findings suggested that the reduction of the inhibitory GABAergic tone on kisspeptin neurons necessary for puberty progression and for preovulatory GnRH-LH surges is in part elicited by leptin signaling on GABAergic neurons, thus linking energy homeostasis with reproduction.

In brief, all these studies clearly demonstrate that GABA interacts with kisspeptin to regulate reproduction in a variety of ways along development. This relationship is bidirectional, that is, kisspeptin modulates GABAergic transmission and GABA modulates kisspeptidergic transmission, in addition to coexpression of both factors in the same neuron, all of which finally impact $\mathrm{GnRH}$ neuron physiology. Whether this bidirectional interaction between kisspeptin and GABA is also reciprocal remains to be established.

\section{Interactions of kisspeptin with GABA in extra hypothalamic sites}

As mentioned earlier, kisspeptin neuron populations outside the hypothalamus have also been described in areas that can affect reproduction in different ways.

$\mathrm{Li}$ et al. (2015) demonstrated that antagonism of GABAAR specifically in the medial posterodorsal amygdala (MePD) advanced the timing of puberty, implying that normally the GABAergic input from this area restrains puberty onset; the opposite effect 
was true of glutamatergic input. These results, together with previous observations, suggest that the amygdala, an area involved in controlling many social and reproductive behaviors, participates in pubertal awakening through its GABAergic and glutamatergic neural systems.. The amygdala sends efferents to the mPOA, rich in $\mathrm{GnRH}$ neurons, and also to the AVPV/PeN and ARC, rich in kisspeptin neurons, through which it could exert its effects. In addition, the MeA also contains kisspeptin neurons (Kim et al. 2011) involved in the regulation of various aspects of reproduction such as puberty timing, male sexual behavior, modulation of gonadotropin release and pulsatility (Comninos et al. 2016, Gresham et al. 2016, Adekunbi et al. 2017, Pineda et al. 2017, Comninos \& Dhillo 2018) that could be modulated by intra-amygdala GABA and glutamate.

Several studies propose the existence of various types of GABA neurons in the amygdala (Veinante et al. 1997, Bian 2013, Keshavarzi et al. 2014). A very recent work from Aggarwal et al. demonstrated that $71 \%$ of MeA kisspeptin neurons also coexpress Vgat, a marker for GABAergic neurons; these authors also demonstrated that this population of kisspeptin neurons process sexually relevant olfactory signals to influence reproductive hormone levels in male mice (Aggarwal et al. 2018). Our results show that 66\% of detectable Kiss 1 neurons in the MeA coexpress Gabab1 subunit mRNA of the GABAB receptor (Di Giorgio et al. 2014). Interestingly, a dramatic increase in Kiss 1 expression was observed in extrahypothalamic regions, such as the MeA, of GABAB1KO mice of both sexes. These increased extrahypothalamic Kiss 1 levels in GABAB1KO mice were not sex steroids dependent and appeared after puberty. These findings suggested that GABABR signaling may normally inhibit Kiss 1 expression in the MeA of adult mice (Di Giorgio et al. 2014). Our findings also indicate that both E2 and GABA, through GABABRs, independently regulate extra-hypothalamic Kiss 1 cell populations (Stephens et al. 2018). As GABAB1KO females have impaired reproduction, a marked increase in MeA kisspeptin input may participate in the alterations observed. It is our aim to further analyze the effect of GABABRs on Kiss 1 neurons in these extra-hypothalamic areas in the new Kiss 1-GABAB1KO mice, lacking GABABRs exclusively in Kiss 1 cells, recently developed in our laboratory (Di Giorgio NP, Tabares F, Bizzozzero M, Bourguignon NS, Bettler B, Libertun C, and Lux-Lantos $\mathrm{V}$, poster presentation ICN, Toronto 2018).

All these results propose that kisspeptin and GABA also interact in the MeA to regulate various aspects of reproduction. The physiological relevance of this interaction in other extra hypothalamic kisspeptinexpressing nuclei such as the BNST or the LS is still unknown.

\section{Conclusion}

In sum, these findings demonstrate that GABA, acting on both its GABAA and GABABRs, interacts with kisspeptin in the regulation of reproduction. Salient examples of these interactions are the following:

(a) Early in development, GABA seems to modulate Kiss1 expression: in embryonic stages, GABA acting on GABAA receptors increases Kiss1 expression, and early postnatally $G A B A B$ receptors also seem to increase Kiss 1 expression in the ARC but not in the AVPV/PeN, as in the absence of GABAB signaling the expression declines. Whether GABA exerts these effects directly on kisspeptin neurons is currently unknown.

(b) In the prepubertal period, central restrain of $\mathrm{GnRH}$ release is mediated by GABA acting on GABAAR on kisspeptin neurons in monkeys and humans. Whether this mechanism is also present in rodents is still under investigation.

(c) In adults, these interactions have been more extensively investigated and are more complex. Interesting examples postulate that the AVPV/PeN neuron population that coexpresses kisspeptin and GABA provides an important double excitatory input to GnRH neurons at the time of ovulation and also that the hyperpolarizing stimulus needed for preovulatory rebound burst firing of kisspeptin neurons is mediated by GABAB receptors (and also $\mu$ and $\mathrm{K}$ opioid receptor); therefore, absence of $\mathrm{GABAB}$ signaling at this critical time may compromise the preovulatory surge.

(d) Antagonism of GABAAR specifically in the medial amygdala advanced the timing of puberty probably by disinhibiting kisspeptin neurons. Moreover, a high percentage of MeA kisspeptin neurons are also GABAergic in nature and they convey sexually relevant olfactory signals to influence reproductive hormone levels. Nevertheless, amygdala interactions of kisspeptin and GABA in the control of reproduction need further investigation.

As shown, these interactions differ depending on the kisspeptin neuron population in question and the stage of development. Alterations in each of these populations can lead to various physiopathological consequences in the reproductive axis.

In addition, especially regarding GABABRs, much information is still missing on: (a) how they regulate Kiss 1 expression, and whether this is age dependent, (b) when Kiss 1 neurons start expressing GABABRs and whether they can influence neurite growth, synapse formation and plasticity in these neurons, as demonstrated in other systems, (c) whether the absence of the hyperpolarizing effects of GABABR stimulation on Kiss 1 neurons is compensated by the action of opioids or whether it 
disturbs the triggering of the preovulatory kisspeptin surge. All these questions warrant further studies that will enhance our understanding of the neural control of reproduction.

\section{Declaration of interest}

The authors declare that there is no conflict of interest that could be perceived as prejudicing the impartiality of this review.

\section{Funding}

This work was supported by Consejo Nacional de Investigaciones Científicas y Técnicas (CONICET PIP 2013-571 to V L L), Agencia Nacional de Promoción Científica y Técnica (ANPCyT, PICT 2013-061 to C L and PICT $2012 \mathrm{~N}^{\circ} 707$ to V L L, PICT 2015 N $^{\circ} 2795$ to N P D G) and Universidad de Buenos Aires (UBA, 20020130100006BA 2014-2017 to C L), Argentina. The authors also thank Fundación René Barón and Fundación Williams, Argentina, for their generous support.

\section{References}

Adekunbi DA, Li XF, Li S, Adegoke OA, Iranloye BO, Morakinyo AO, Lightman SL, Taylor PD, Poston L \& O'Byrne KT 2017 Role of amygdala kisspeptin in pubertal timing in female rats. PLOS ONE 12 e0183596. (https://doi.org/10.1371/journal.pone.0183596)

Aggarwal S, Tang C, Sing K, Kim HW, Millar RP \& Tello JA 2018 Medial amygdala Kiss1 neurons mediate female pheromone stimulation of LH in male mice. Neuroendocrinology Epub. (https://doi. org/10.1159/000496106)

Akema T \& Kimura F 1991 The mode of GABAB receptor-mediated inhibition of the preovulatory luteinizing hormone surge in female rats. Brain Research 562 169-172. (https://doi.org/10.1016/00068993(91)91203-D)

Alreja M 2013 Electrophysiology of kisspeptin neurons. Advances in Experimental Medicine and Biology 784 349-362. (https://doi. org/10.1007/978-1-4614-6199-9_16)

Barash IA, Cheung CC, Weigle DS, Ren H, Kabigting EB, Kuijper JL, Clifton DK \& Steiner RA 1996 Leptin is a metabolic signal to the reproductive system. Endocrinology 137 3144-3147. (https://doi. org/10.1210/endo.137.7.8770941)

Beltramo M, Dardente H, Cayla X \& Caraty A 2014 Cellular mechanisms and integrative timing of neuroendocrine control of $\mathrm{GnRH}$ secretion by kisspeptin. Molecular and Cellular Endocrinology 382 387-399. (https:// doi.org/10.1016/j.mce.2013.10.015)

Bian X 2013 Physiological and morphological characterization of GABAergic neurons in the medial amygdala. Brain Research 1509 8-19. (https://doi.org/10.1016/j.brainres.2013.03.012)

Bizzozzero M, Di Giorgio N, Bourguignon N, Tabares F, Stephens SB, Kauffman AS, Libertun C \& Lux-Lantos VA 2017 Effects of a GABAB antagonist on brain Kiss1 expression in mice. Endocrine Reviews 38 (Supplement).

Budefeld T, Tobet SA \& Majdic G 2016 The influence of gonadal steroid hormones on immunoreactive kisspeptin in the preoptic area and arcuate nucleus of developing agonadal mice with a genetic disruption of steroidogenic factor 1 . Neuroendocrinology 103 248-258. (https:// doi.org/10.1159/000437166)

Catalano PN, Bonaventura MM, Silveyra P, Bettler B, Libertun C \& Lux-Lantos VA 2005 GABA(B1) knockout mice reveal alterations in prolactin levels, gonadotropic axis, and reproductive function. Neuroendocrinology $\mathbf{8 2}$ 294-305. (https://doi. org/10.1159/000093128)

Check JH 2013 The interrelationship of sleep, biologic clocks, neurotransmitters, gonadotropins and pubertal development. Clinical and Experimental Obstetrics and Gynecology 40 7-14.
Chehab FF, Lim ME \& Lu R 1996 Correction of the sterility defect in homozygous obese female mice by treatment with the human recombinant leptin. Nature Genetics 12 318-320. (https://doi. org/10.1038/ng0396-318)

Clarkson J \& Herbison AE 2006 Development of GABA and glutamate signaling at the $\mathrm{GnRH}$ neuron in relation to puberty. Molecular and Cellular Endocrinology 254-255 32-38. (https://doi.org/10.1016/j. mce.2006.04.036)

Clarkson J \& Herbison AE 2016 Hypothalamic control of the male neonatal testosterone surge. Philosophical Transactions of the Royal Society B 371 20150115. (https://doi.org/10.1098/rstb.2015.0115)

Clarkson J, d'Anglemont de Tassigny X, Colledge WH, Caraty A \& Herbison AE 2009 Distribution of kisspeptin neurones in the adult female mouse brain. Journal of Neuroendocrinology 21 673-682. (https://doi.org/10.1111/j.1365-2826.2009.01892.x)

Comninos AN \& Dhillo WS 2018 Emerging roles of kisspeptin in sexual and emotional brain processing. Neuroendocrinology 106 195-202. (https://doi.org/10.1159/000481137)

Comninos AN, Anastasovska J, Sahuri-Arisoylu M, Li X, Li S, Hu M, Jayasena CN, Ghatei MA, Bloom SR, Matthews PM et al. 2016 Kisspeptin signaling in the amygdala modulates reproductive hormone secretion. Brain Structure and Function 221 2035-2047. (https://doi.org/10.1007/ s00429-015-1024-9)

Craig MT \& McBain CJ 2014 The emerging role of GABAB receptors as regulators of network dynamics: fast actions from a 'slow' receptor? Current Opinion in Neurobiology 26 15-21. (https://doi.org/10.1016/j. conb.2013.10.002)

Cravo RM, Margatho LO, Osborne-Lawrence S, Donato J Jr, Atkin S, Bookout AL, Rovinsky S, Frazao R, Lee CE, Gautron L et al. 2011 Characterization of Kiss1 neurons using transgenic mouse models. Neuroscience 173 37-56. (https://doi.org/10.1016/j. neuroscience.2010.11.022)

de Luca C, Kowalski TJ, Zhang Y, Elmquist JK, Lee C, Kilimann MW, Ludwig T, Liu SM \& Chua SC Jr 2005 Complete rescue of obesity, diabetes, and infertility in $\mathrm{db} / \mathrm{db}$ mice by neuron-specific LEPR-B transgenes. Journal of Clinical Investigation 115 3484-3493. (https://doi. org/10.1172/JCl24059)

de Roux N, Genin E, Carel JC, Matsuda F, Chaussain JL \& Milgrom E 2003 Hypogonadotropic hypogonadism due to loss of function of the KiSS1derived peptide receptor GPR54. PNAS 100 10972-10976. (https://doi. org/10.1073/pnas.1834399100)

DeFazio RA, Heger S, Ojeda SR \& Moenter SM 2002 Activation of A-type gamma-aminobutyric acid receptors excites gonadotropin-releasing hormone neurons. Molecular Endocrinology 16 2872-2891. (https://doi. org/10.1210/me.2002-0163)

DeFazio RA, Elias CF \& Moenter SM 2014 GABAergic transmission to kisspeptin neurons is differentially regulated by time of day and estradiol in female mice. Journal of Neuroscience 34 16296-16308. (https://doi. org/10.1523/JNEUROSCI.3057-14.2014)

Di Giorgio NP, Catalano PN, Lopez PV, Gonzalez B, Semaan SJ, Lopez GC, Kauffman AS, Rulli SB, Somoza GM, Bettler B et al. 2013 Lack of functional GABAB receptors alters Kiss1, Gnrh1 and Gad1 mRNA expression in the medial basal hypothalamus at postnatal Day 4. Neuroendocrinology 98 212-223. (https://doi. org/10.1159/000355631)

Di Giorgio NP, Semaan SJ, Kim J, Lopez PV, Bettler B, Libertun C, Lux-Lantos VA \& Kauffman AS 2014 Impaired GABAB receptor signaling dramatically up-regulates Kiss1 expression selectively in nonhypothalamic brain regions of adult but not prepubertal mice. Endocrinology 155 1033-1044. (https://doi.org/10.1210/en.20131573)

Donoso AO \& Banzan AM 1986 Blockade of the LH surge and ovulation by GABA-T inhibitory drugs that increase brain GABA levels in rats. Psychoneuroendocrinology 11 429-435. (https://doi.org/10.1016/03064530(86)90004-1)

Ducret E, Gaidamaka G \& Herbison AE 2010 Electrical and morphological characteristics of anteroventral periventricular nucleus kisspeptin and other neurons in the female mouse. Endocrinology 151 2223-2232. (https://doi.org/10.1210/en.2009-1480)

Dungan HM, Clifton DK \& Steiner RA 2006 Minireview: kisspeptin neurons as central processors in the regulation of gonadotropinreleasing hormone secretion. Endocrinology 147 1154-1158. (https:// doi.org/10.1210/en.2005-1282) 
Fiszman ML \& Schousboe A 2004 Role of calcium and kinases on the neurotrophic effect induced by gamma-aminobutyric acid. Journal of Neuroscience Research 76 435-441. (https://doi.org/10.1002/jnr.20062)

Fueshko SM, Key S \& Wray S 1998 GABA inhibits migration of luteinizing hormone-releasing hormone neurons in embryonic olfactory explants. Journal of Neuroscience 18 2560-2569. (https://doi.org/10.1523/ JNEUROSCI.18-07-02560.1998)

Gaiarsa JL \& Porcher C 2013 Emerging neurotrophic role of GABAB receptors in neuronal circuit development. Frontiers in Cellular Neuroscience 7 206. (https://doi.org/10.3389/fncel.2013.00206)

Galanopoulou AS 2008 Sexually dimorphic expression of KCC2 and GABA function. Epilepsy Research 80 99-113. (https://doi.org/10.1016/j. eplepsyres.2008.04.013)

Gay VL \& Plant TM 1987 N-methyl-D,L-aspartate elicits hypothalamic gonadotropin-releasing hormone release in prepubertal male rhesus monkeys (Macaca mulatta). Endocrinology 120 2289-2296. (https://doi. org/10.1210/endo-120-6-2289)

Gore AC, Wu TJ, Rosenberg JJ \& Roberts JL 1996 Gonadotropin-releasing hormone and NMDA receptor gene expression and colocalization change during puberty in female rats. Journal of Neuroscience $\mathbf{1 6}$ 5281-5289. (https://doi.org/10.1523/JNEUROSCI.16-17-05281.1996)

Gottsch ML, Popa SM, Lawhorn JK, Qiu J, Tonsfeldt KJ, Bosch MA, Kelly MJ, Ronnekleiv OK, Sanz E, McKnight GS et al. 2011 Molecular properties of Kiss1 neurons in the arcuate nucleus of the mouse. Endocrinology 152 4298-4309. (https://doi.org/10.1210/en.2011-1521)

Gresham R, Li S, Adekunbi DA, Hu M, Li XF \& O'Byrne KT 2016 Kisspeptin in the medial amygdala and sexual behavior in male rats. Neuroscience Letters 627 13-17. (https://doi.org/10.1016/j.neulet.2016.05.042)

Han SK, Todman MG \& Herbison AE 2004 Endogenous GABA release inhibits the firing of adult gonadotropin-releasing hormone neurons. Endocrinology 145 495-499. (https://doi.org/10.1210/en.2003-1333)

Herbison AE \& Moenter SM 2011 Depolarising and hyperpolarising actions of $\mathrm{GABA}(\mathrm{A})$ receptor activation on gonadotrophin-releasing hormone neurones: towards an emerging consensus. Journal of Neuroendocrinology 23 557-569. (https://doi.org/10.1111/j.13652826.2011.02145.x)

Jarry H, Leonhardt S, Schwarze T \& Wuttke W 1995 Preoptic rather than mediobasal hypothalamic amino acid neurotransmitter release regulates $\mathrm{GnRH}$ secretion during the estrogen-induced $\mathrm{LH}$ surge in the ovariectomized rat. Neuroendocrinology 62 479-486. (https://doi. org/10.1159/000127037)

Kaiser UB \& Kuohung W 2005 KiSS-1 and GPR54 as new players in gonadotropin regulation and puberty. Endocrine 26 277-284. (https:// doi.org/10.1385/ENDO:26:3:277)

Kanasaki H, Tumurbaatar T, Oride A, Hara T, Okada H \& Kyo S 2017 Gamma-aminobutyric acidA receptor agonist, muscimol, increases KiSS1 gene expression in hypothalamic cell models. Reproductive Medicine and Biology 16 386-391. (https://doi.org/10.1002/rmb2.12061)

Kauffman AS \& Smith JT 2013 Kisspeptin signaling in reproductive biology. In:Journal Transactions Advances in Experimental Medicine and Biology pp 1-784. (https://doi.org/10.1007/978-1-4614-6199-9)

Keen KL, Burich AJ, Mitsushima D, Kasuya E \& Terasawa E 1999 Effects of pulsatile infusion of the $\mathrm{GABA}(\mathrm{A})$ receptor blocker bicuculline on the onset of puberty in female rhesus monkeys. Endocrinology $\mathbf{1 4 0}$ 5257-5266. (https://doi.org/10.1210/endo.140.11.7139)

Keshavarzi S, Sullivan RK, lanno DJ \& Sah P 2014 Functional properties and projections of neurons in the medial amygdala. Journal of Neuroscience 34 8699-8715. (https://doi.org/10.1523/JNEUROSCI.1176-14.2014)

Kilb W, Kirischuk S \& Luhmann HJ 2013 Role of tonic GABAergic currents during pre- and early postnatal rodent development. Frontiers in Neural Circuits 7 139. (https://doi.org/10.3389/fncir.2013.00139)

Kim J, Semaan SJ, Clifton DK, Steiner RA, Dhamija S \& Kauffman AS 2011 Regulation of Kiss1 expression by sex steroids in the amygdala of the rat and mouse. Endocrinology 152 2020-2030. (https://doi.org/10.1210/ en.2010-1498)

Kurian JR, Keen KL, Guerriero KA \& Terasawa E 2012 Tonic control of kisspeptin release in prepubertal monkeys: implications to the mechanism of puberty onset. Endocrinology 153 3331-3336. (https:// doi.org/10.1210/en.2012-1221)

Lauder JM, Liu J, Devaud L \& Morrow AL 1998 GABA as a trophic factor for developing monoamine neurons. Perspectives on Developmental Neurobiology 5 247-259.
Lehman MN, Coolen LM, Steiner RA, Neal-Perry G, Wang L, Moenter SM, Moore AM, Goodman RL, Hwa-Yeo S, Padilla SL et al. 2018 The 3rd World Conference on Kisspeptin, 'kisspeptin 2017: brain and beyond': unresolved questions, challenges and future directions for the field. Journal of Neuroendocrinology e12600. (https://doi.org/10.1111/ jne.12600)

Leon S, Barroso A, Vazquez MJ, Garcia-Galiano D, Manfredi-Lozano M, Ruiz-Pino F, Heras V, Romero-Ruiz A, Roa J, Schutz G et al. 2016 Direct actions of kisspeptins on GnRH neurons permit attainment of fertility but are insufficient to fully preserve gonadotropic axis activity. Scientific Reports 6 19206. (https://doi.org/10.1038/srep19206)

Leranth C, Maclusky NJ, Sakamoto H, Shanabrough M \& Naftolin F 1985 Glutamic acid decarboxylase-containing axons synapse on LHRH neurons in the rat medial preoptic area. Neuroendocrinology 40 536-539. (https://doi.org/10.1159/000124127)

Li XF, Hu MH, Hanley BP, Lin YS, Poston L, Lightman SL \& O'Byrne KT 2015 The posterodorsal medial amygdala regulates the timing of puberty onset in female rats. Endocrinology 156 3725-3736. (https://doi. org/10.1210/en.2015-1366)

Liu X \& Herbison AE 2016 Kisspeptin regulation of neuronal activity throughout the central nervous system. Endocrinology and Metabolism 31 193-205. (https://doi.org/10.3803/EnM.2016.31.2.193)

Liu X, Porteous R, d'Anglemont de Tassigny X, Colledge WH, Millar R, Petersen SL \& Herbison AE 2011Frequency-dependent recruitment of fast amino acid and slow neuropeptide neurotransmitter release controls gonadotropin-releasing hormone neuron excitability. Journal of Neuroscience 31 2421-2430. (https://doi.org/10.1523/ JNEUROSCI.5759-10.2011)

Luhmann HJ, Fukuda A \& Kilb W 2015 Control of cortical neuronal migration by glutamate and GABA. Frontiers in Cellular Neuroscience 9 4. (https://doi.org/10.3389/fncel.2015.00004)

Maffucci JA \& Gore AC 2009 Hypothalamic neural systems controlling the female reproductive life cycle gonadotropin-releasing hormone, glutamate, and GABA. In International Review of Cell and Molecular Biology, pp 69-127. Edn 274. Ed WJ Kwang. Burlington: Academic Press. (https://doi.org/10.1016/S1937-6448(08)02002-9)

Marshall CJ, Desroziers E, McLennan T \& Campbell RE 2017 Defining subpopulations of arcuate nucleus GABA neurons in male, female, and prenatally androgenized female mice. Neuroendocrinology 105 157-169. (https://doi.org/10.1159/000452105)

Martin C, Navarro VM, Simavli S, Vong L, Carroll RS, Lowell BB \& Kaiser UB 2014 Leptin-responsive GABAergic neurons regulate fertility through pathways that result in reduced kisspeptinergic tone. Journal of Neuroscience 34 6047-6056. (https://doi.org/10.1523/ JNEUROSCI.3003-13.2014)

McCarthy MM, Auger AP \& Perrot-Sinal TS 2002 Getting excited about GABA and sex differences in the brain. Trends in Neurosciences 25 307-312. (https://doi.org/10.1016/S0166-2236(02)02182-3)

McCarthy MM, Schwarz JM, Wright CL \& Dean SL 2008 Mechanisms mediating oestradiol modulation of the developing brain. Journal of Neuroendocrinology 20 777-783. (https://doi.org/10.1111/j.13652826.2008.01723.x)

Millar RP \& Babwah AV 2015 KISS1R: hallmarks of an effective regulator of the neuroendocrine axis. Neuroendocrinology 101 193-210. (https:// doi.org/10.1159/000381457)

Moenter SM, Chu Z \& Christian CA 2009 Neurobiological mechanisms underlying oestradiol negative and positive feedback regulation of gonadotrophin-releasing hormone neurones. Journal of Neuroendocrinology 21 327-333. (https://doi.org/10.1111/j.13652826.2009.01826.x)

Neal-Perry G, Lebesgue D, Lederman M, Shu J, Zeevalk GD \& Etgen AM 2009 The excitatory peptide kisspeptin restores the luteinizing hormone surge and modulates amino acid neurotransmission in the medial preoptic area of middle-aged rats. Endocrinology 150 3699-3708. (https://doi.org/10.1210/en.2008-1667)

Pielecka-Fortuna J \& Moenter SM 2010 Kisspeptin increases gammaaminobutyric acidergic and glutamatergic transmission directly to gonadotropin-releasing hormone neurons in an estradiol-dependent manner. Endocrinology 151 291-300. (https://doi.org/10.1210/en.20090692)

Pielecka-Fortuna J, Chu Z \& Moenter SM 2008 Kisspeptin acts directly and indirectly to increase gonadotropin-releasing hormone neuron 
activity and its effects are modulated by estradiol. Endocrinology $\mathbf{1 4 9}$ 1979-1986. (https://doi.org/10.1210/en.2007-1365)

Piet R, Kalil B, McLennan T, Porteous R, Czieselsky K \& Herbison AE 2018 Dominant neuropeptide cotransmission in kisspeptin-GABA regulation of $\mathrm{GnRH}$ neuron firing driving ovulation. Journal of Neuroscience $\mathbf{3 8}$ 6310-6322. (https://doi.org/10.1523/JNEUROSCI.0658-18.2018)

Pineda R, Plaisier F, Millar RP \& Ludwig M 2017 Amygdala kisspeptin neurons: putative mediators of olfactory control of the gonadotropic axis. Neuroendocrinology 104 223-238. (https://doi.org/10.1159/000445895)

Roa J, Aguilar E, Dieguez C, Pinilla L \& Tena-Sempere M 2008 New frontiers in kisspeptin/GPR54 physiology as fundamental gatekeepers of reproductive function. Frontiers in Neuroendocrinology 29 48-69. (https://doi.org/10.1016/j.yfrne.2007.07.002)

Robinson JE, Kendrick KM \& Lambart CE 1991 Changes in the release of gamma-aminobutyric acid and catecholamines in the preoptic/septal area prior to and during the preovulatory surge of luteinizing hormone in the ewe. Journal of Neuroendocrinology 3 393-399. (https://doi. org/10.1111/j.1365-2826.1991.tb00293.x)

Ronnekleiv OK, Zhang C, Bosch MA \& Kelly MJ 2015 Kisspeptin and gonadotropin-releasing hormone neuronal excitability: molecular mechanisms driven by 17beta-estradiol. Neuroendocrinology 102 184-193. (https://doi.org/10.1159/000370311)

Semaan SJ \& Kauffman AS 2015 Daily successive changes in reproductive gene expression and neuronal activation in the brains of pubertal female mice. Molecular and Cellular Endocrinology 401 84-97. (https://doi. org/10.1016/j.mce.2014.11.025)

Semaan SJ, Tolson KP \& Kauffman AS 2013 The development of kisspeptin circuits in the Mammalian brain. Advances in Experimental Medicine and Biology $784221-252$.

Seminara SB 2006 Mechanisms of disease: the first kiss-a crucial role for kisspeptin-1 and its receptor, G-protein-coupled receptor 54, in puberty and reproduction. Nature Clinical Practice: Endocrinology and Metabolism 2 328-334. (https://doi.org/10.1038/ncpendmet0139)

Seminara SB, Messager S, Chatzidaki EE, Thresher RR, Acierno JS Jr, Shagoury JK, Bo-Abbas Y, Kuohung W, Schwinof KM, Hendrick AG et al. 2003 The GPR54 gene as a regulator of puberty. New England Journal of Medicine 349 1614-1627. (https://doi.org/10.1056/NEJMoa035322)

Stephens SBZ, Di Giorgio NP, Liaw RB, Parra RA, Yang JA, Chahal N, Lux-Lantos VA \& Kauffman AS 2018 Estradiol-dependent and -independent stimulation of Kiss1 expression in the Amygdala, BNST, and lateral septum of mice. Endocrinology 159 3389-3402. (https://doi. org/10.1210/en.2018-00583)

Suzuki M, Nishihara M \& Takahashi M 1995 Hypothalamic gonadotropinreleasing hormone gene expression during rat estrous cycle. Endocrine Journal 42 789-796. (https://doi.org/10.1507/endocrj.42.789)

Terasawa E \& Fernandez DL 2001 Neurobiological mechanisms of the onset of puberty in primates. Endocrine Reviews 22 111-151. (https:// doi.org/10.1210/edrv.22.1.0418)

Terasawa E, Kurian JR, Guerriero KA, Kenealy BP, Hutz ED \& Keen KL 2010 Recent discoveries on the control of gonadotrophin-releasing hormone neurones in nonhuman primates. Journal of Neuroendocrinology 22 630-638. (https://doi.org/10.1111/j.1365-2826.2010.02027.x)

Tobet SA, Bless EP \& Schwarting GA 2001 Developmental aspect of the gonadotropin-releasing hormone system. Molecular and Cellular Endocrinology 185 173-184. (https://doi.org/10.1016/S03037207(01)00616-5)

Tobet S, Knoll JG, Hartshorn C, Aurand E, Stratton M, Kumar P, Searcy B \& McClellan K 2009 Brain sex differences and hormone influences: a moving experience? Journal of Neuroendocrinology 21 387-392. (https://doi.org/10.1111/j.1365-2826.2009.01834.x)

Urbanski HF \& Ojeda SR 1987 Activation of luteinizing hormonereleasing hormone release advances the onset of female puberty. Neuroendocrinology 46 273-276. (https://doi.org/10.1159/000124831)

Veinante P, Stoeckel ME \& Freund-Mercier MJ 1997 GABA- and peptideimmunoreactivities co-localize in the rat central extended amygdala. NeuroReport 8 2985-2989. (https://doi.org/10.1097/00001756199709080-00035)

Wierman ME, Kiseljak-Vassiliades K \& Tobet S 2011 Gonadotropinreleasing hormone $(\mathrm{GnRH})$ neuron migration: initiation, maintenance and cessation as critical steps to ensure normal reproductive function. Frontiers in Neuroendocrinology 32 43-52. (https://doi.org/10.1016/j. yfrne.2010.07.005)

Zhang C, Roepke TA, Kelly MJ \& Ronnekleiv OK 2008 Kisspeptin depolarizes gonadotropin-releasing hormone neurons through activation of TRPC-like cationic channels. Journal of Neuroscience $\mathbf{2 8}$ 4423-4434. (https://doi.org/10.1523/JNEUROSCl.5352-07.2008)

Zhang C, Bosch MA, Ronnekleiv OK \& Kelly MJ 2009 Gamma-aminobutyric acid $B$ receptor mediated inhibition of gonadotropin-releasing hormone neurons is suppressed by kisspeptin-G protein-coupled receptor 54 signaling. Endocrinology 150 2388-2394. (https://doi.org/10.1210/ en.2008-1313)

Zhang C, Tonsfeldt KJ, Qiu J, Bosch MA, Kobayashi K, Steiner RA, Kelly MJ \& Ronnekleiv OK 2013 Molecular mechanisms that drive estradioldependent burst firing of Kiss1 neurons in the rostral periventricular preoptic area. American Journal of Physiology: Endocrinology and Metabolism 305 E1384-E1397. (https://doi.org/10.1152/ ajpendo.00406.2013)

Ziskind-Conhaim L 1998 Physiological functions of GABA-induced depolarizations in the developing rat spinal cord. Perspectives on Developmental Neurobiology 5 279-287.

Received 5 October 2018

First decision 13 November 2018

Revised manuscript received 1 February 2019

Accepted 7 March 2019 